November 2010, revised April 2011 - Journal of Coastal Conservation

\title{
Coastal retreat and/or advance adjacent to defences in England and Wales
}

Sally Brown (sb20@ soton.ac.uk, Telephone: 02380 594796. Fax: 02380 677519).

Max Barton (M.E.Barton@ @oton.ac.uk)

Robert Nicholls (R.J.Nicholls@soton.ac.uk)

School of Civil Engineering and the Environment, University of Southampton, University Road, Highfield, Southampton, UK. SO17 1BJ. 


\begin{abstract}
Retreat and advance of shoreline position occurs naturally, and also as a result of defences which are constructed to prevent erosion and flooding. Retreat more commonly manifests itself down-drift of defences due to sediment deficit causing the coast to become 'set-back'. Advance normally develops due to sediment accumulation up-drift of a barrier inhibiting longshore drift, resulting in the coast becoming 'set-forward'.
\end{abstract}

Many examples of set-backs and set-forwards are recorded, but their location, number and cause is not known on a national scale. Using the Futurecoast aerial photographs, approximately 200 localities were identified as set-back or set-forward in England and Wales, with half situated in the Eastern and South East regions of England. Half of the total setbacks or set-forwards were on cliffed coasts, and half on low-lying coasts.

Without local knowledge it is difficult to distinguish between set-backs and set-forwards. Setbacks often indicate higher retreat rates, thus threatening cliff-top infrastructure which requires defence upgrade and extensions, as well as raising maintenance costs. Monitoring set-backs is important for shoreline management, because as retreat continues, set-backs evolve and artificial headlands form and grow. This is reinforced by the shift from hard defence policies towards softer engineering approaches, managed realignment and limited intervention.

Keywords: Coastal defences; set-back; set-forward; mapping; headlands. 


\section{Introduction}

Erosion dominates over accretion on most of the world's beaches (Bird 1985) and in 2004, damage due to coastal erosion in England was estimated to have cost $£ 14.4$ million (including property, land, infrastructure and transport disruption or loss). With climate change and continued development, it is estimated that this could rise to as much as $£ 126$ million per annum by the 2080s (Evans et al. 2004). It is important to understand on a national scale what controls or aggravates erosion so that the coastal zone can be effectively managed. For instance, erosion has often been amplified or directly caused by human interference (Eurosion 2004). Coastal structures, such as jetties, breakwaters, groynes and seawalls have been built widely around the world to control shoreline position for hundreds of years to reduce erosion and flooding, and to aid navigation (Brampton 2002; Komar 1976). However they have knock-on impacts on the adjacent coastline as the sediment budget is often altered, leading to the retreat or advancement of shoreline position.

This paper is intended to raise the awareness of the long-term implications of coastal engineering works and provides a starting point for detailed studies into retreat or advance of the shoreline. It also determines potential problem areas due to human interference, from a national perspective. This research provides basic statistics and allows investigation into the factors that control and influence the growth of artificial shoreline change on a national scale, such as defence location and termination, geology, morphology and topography. The structure of the paper is as follows:

a) Definition of the creation of advances and retreat of shoreline position.

b) Description of the history relating to shoreline changes adjacent to defences.

c) Mapping of localities of shoreline change adjacent to defences in England and Wales. 
d) Discussion of case studies of shoreline change, specifically those related to shoreline retreat on cliffed coastlines as these sites are straight forward to identify.

\section{Creation of advances and retreat of shoreline position: shoreline 'set-backs' and 'set-}

\section{forwards'}

Coastal defences fix the shoreline position and alter the sediment budget. For example, where sediment accumulates up-drift of groynes and other defences it creates protective beaches, advancing the shoreline (creating a 'set-forward') and reducing erosion. On the down-drift coast, the sediment budget is also changed. The down-drift coast is usually starved of sediment, often resulting in retreat and a 'set-back' of shoreline position with respect to the defences, due to the continued activity of wave attack and sub-aerial processes. The rate of retreat or advancement depends on the frequency of extreme events and meteorological conditions, and other site conditions such as the magnitude of longshore drift, sediment type, rock hardness, exposure of the shore platform and the rate of sea-level rise. The creation of coastline set-forwards and set-backs via accretion and erosion is illustrated in Figures 1a (a groyne field on a cliffed coastline) and Figure $1 \mathrm{~b}$ (a single barrier on a beach or adjacent to a debouching river, which may be in a cliffed or low-lying environment). In Figure 1a, the advance of the shoreline may not continue up-drift of the groyne field, as there may be insufficient sediment to halt retreat. Thus over many decades the defended coast forms an artificial headland as shown in Figure 1a(iii). For the examples in Figures 1a and 1b, downdrift set-backs are not necessarily due to accelerated retreat as they can also occur due to the continued retreat of the coast if the up-drift position is held (known in shoreline management as 'hold the line' (Department for Environment, Food and Rural Affairs 2009; Leafe et al. 1998)). 
The generic terms 'set-back' and 'set-forward' are used as opposed to the process terms 'eroding' and 'accreting' as it can be difficult to determine which process is happening due to multiple sediment process and human interference at one site. Additionally, sites may have eroded historically, so are set-back, but are not presently eroding. Determining whether a site is set-back or set-forward involves more detailed research into historical shoreline evolution (such as direction of longshore drift), including the construction of coastal defences (including beach nourishment). Cliffs and beaches behave differently. A cliff is inherently erosional so can only retreat, thus producing set-backs (see Figure 2 illustrating Barton-onSea, Hampshire). Beaches (and low-lying coasts) erode or accrete depending on the sediment budget so can have set-backs and set-forwards (see Figure 3 illustrating Rye, East Sussex).

Set-backs can also develop due to defence removal. For example, at Happisburgh, North Norfolk, wooden groynes and a revetment were constructed in 1958 and 1968. Due to lack of maintenance, a 900m section of defences failed from the 1980s and was removed (Coastal Concern Action Group 2008; Evans et al. 2004) reinitiating cliff retreat, whilst the adjacent cliffs continued to be protected and had minimal erosion. Subsequently, the unprotected coast set-back 100m over a 14 year period (Figure 4). Thus set-backs and setforwards are caused by:

(1) a natural break or abrupt change in shoreline orientation due to geology, morphology and geography, such as a large landslide or a river;

Or anthropogenically;

(2) a reduction in sediment supply normally down-drift of an artificial barrier, including a reduction in input along the defended section (e.g. from cliffs);

(3) an accumulation of sediment up-drift of an artificial barrier; 
(4) defence removal causing a break in defences;

(5) a combination of 1, 2, 3, 4 .

Due to the number of causes of set-backs and set-forwards as listed above, these features cannot be seen as permanent features of the coast, but changing features, subject to anthropogenic and environmental conditions. Extending defences can initiate new set-backs, for example:

- repeated defence extensions resulted in headland formation at Hornsea, Holderness (Brown 2008);

- beach nourishment resulted in set-forwards such as at West Bay, Dorset (West Dorset District Council 2002);

- changes to longshore drift potentially obscured past changes caused by defences. For instance, at Kessingland, Suffolk a set-back developed adjacent to a sea wall (Steers 1951), but afterwards this was obscured by the migration of a ness (a large crescent shaped body of sediment)).

In this study, the majority of set-backs discussed are linked to anthropogenic causes, but not until a thorough investigation is made into previous site conditions, can one assume this is the case, and in reality a set-back may occur due to natural and anthropogenic causes. This is discussed in 'Study limitations'.

Evidence for set-backs and set-forwards are derived by analysing shoreline change indicators on historic maps such as low and high water and the cliff base and cliff top (for example, Brown 2008; Crowell et al. 1991; Nicholls et al. 2000). Where the shoreline is setforward, wave attack on the back of the beach or cliff is reduced, or removed. Set-back, 
particularly on the down-drift coast can be particularly severe as the sediment deficit potentially increases the retreat rate (Dean 1996; Komar 1976) (a phenomenon known as the terminal groyne effect). Such erosion problems often 'migrate' down-drift, raising issues of land and infrastructure loss and defence outflanking (Anderson et al. 1983; Brown et al. submitted; Bruun 1995, 2001; Galgano 1998; Kana et al. 2004; LeBlond 1972; Terpstra and Chrzastowski 1992). Without detailed studies using historical maps, it can be difficult to determine if sites are set-back or set-forward (particularly on low-lying coasts) as the net result looks similar due to the coastal configuration of defences with respect to the undefended coast, and the coastal dynamics, such as direction of longshore drift, and erosion or accretion of the coast adjacent to a hard structure. Thus the focus of case studies discussed in this paper (in 'Results and discussion') will be on the cliffed sites where we are confident we are dealing with set-backs. Case studies were selected due to the availability of good data, a long history of defence or where there is rapid retreat, thus providing a clear signal of coastline change. Set-backs are particularly important to study because of their hazardous nature towards cliff-top buildings and infrastructure, and the outflanking effect at the end of the defences.

\section{Set-back and set-forward formation and its history in England and Wales}

For over 150 years, engineers have recognised that defences starve the down-drift coast of sediment and increase retreat rates. The use of defences have expanded due to increasing population and economic base, including the growth of harbours (such as harbour arms and navigational structures including training walls and breakwaters) and the emergence of coastal tourism as an important industry, plus the demand and expectation that land should be protected. As defences grew (particularly in the ad hoc manner prior to Shoreline 
Management Plans (Department for Environment, Food and Rural Affairs 2009)), the number of set-backs increased (both up-drift and down-drift, with down-drift set-backs being more severe), as did the occurrence of problems such as defence outflanking. For example, Hewitt (1844) noted the sediment deficiency down-drift of groynes at Trimingham, Norfolk, and Hutchinson et al. (1980) discussed reports of a reduction in the littoral drift volume downdrift of Folkestone Harbour, Kent, from the mid to late $19^{\text {th }}$ century. At Folkestone Harbour (where the defences and harbour arm were initially constructed from 1807-1810), the severity of down-drift erosion was such that the set-back threatened to outflank the defences, resulting in defence extensions on three occasions in 1861-1863, 1881-1883 and 1897-1905 (Bishop 1973).

These engineering works and many others indicate a long and complex history of human intervention on the coast, resulting in set-backs and set-forwards. For some cases, a locality may be both set-back and set-forward depending on the shoreline indicator analysed. For example, where sediment accumulates up-drift of an artificial barrier, it can result in a set-forward of the shoreline. However, if the additional sediment is insufficient to stop erosion of the cliff base, the cliff top would also become set-back with respect to the adjacent protected cliff.

Set-backs are not always observed down-drift of defences, as sufficient sediment may still be available to maintain the beach or protect the cliff. Furthermore, erosion takes time and an insufficient period may have passed to allow a set-back to develop, or changes in geomorphology may restrict set-back formation. Set-backs, where they exist, can be less distinctive where there is a variable drift direction, or a drift divide (for example, at Blackpool and Sheringham) as land loss is shared between the extremities of the defences. 


\section{Mapping set-backs and set-forwards}

\section{Methodology}

To identify set-backs and set-forwards around England and Wales, a national set of oblique aerial photographs from the Futurecoast study (Halcrow 2002) were analysed. Each set-back or set-forward locality was noted, and where necessary checked against Ordnance Survey maps and aerial photographs, such as Google Earth (Google 2011). Additional data, for example, geological and coastal process information from Futurecoast, geological maps, Shoreline Management Plans and historical defence documentation were obtained from local authorities and libraries. For detailed case studies, natural and artificial set-backs and setforwards were determined by analysing the movement of low and high water and the cliff base and cliff top from a time series of maps, aerial photographs and field surveys. Historical shoreline analysis was undertaken using a Geographical Information System (GIS) augmented by coastal defence history.

\section{Study limitations}

Without further investigations it was not always possible to distinguish between natural and anthropogenic set-back. For example, an outfall at East Runton, North Norfolk acts as a potential littoral drift barrier and is associated with a set-back, but historic map analysis indicates that the set-back was present before outfall construction and hence is at least partly natural. Therefore defences may be located where there is a natural tendency for a set-back or a set-forward, and the phenomenon may be exaggerated for anthropogenic reasons. 
It was not possible to distinguish every set-back within one locality due to the geographical scale of the resources used, as multiple set-backs are often found within a relatively short distance of each other (see Results and discussion). Generally, set-backs have to be tens of metres in size to be mapped and often the defence history of a site is required to determine whether it is a natural or anthropogenic cause. The localities were divided into two groups determined by coastal type, namely cliffed coasts and low lying coasts (as shown in the Appendix).

\section{Results and discussion}

Set-backs and set-forwards: Locality, distribution and coastline stability

Set-back and set-forward sites located around England and Wales are shown in Figures 5 (cliffed coast) and 6 (low-lying coast). Overall, 190 localities were identified, many comprising multiple set-backs or set-forwards. Half of the localities occurred on cliffed sites and half in low-lying areas. The majority of low-lying localities were found in the South East, followed by Wales. Regions with predominantly cliffed set-backs included South East, followed by Eastern England. Overall, approximately half of the 190 localities were situated in the Eastern and South East regions of England (see Table 1). A list of sites is documented in the Appendix (Table A1 lists the localities on cliffed coasts and Table A2 lists the localities on low-lying coasts).

The vast majority of set-backs or set-forwards are considered to be caused by defence construction or removal, rather than by natural means. The principal control of set-back and 
set-forward locations on a national scale is geology, and secondly topography. Defence locations are further influenced by population distribution, plus flood and erosional risks. In England and Wales there is a dominant north-east and south-west trend in geology. Broadly broken down in geographical regions, harder rocks (broadly Palaeozoic or older) are found in the far north of England, Wales and the South West and softer rock (broadly Mesozoic or younger) in the South East, Eastern, Midlands and Yorkshire regions. Set-backs or setforwards in cliffed areas mainly occur in soft rock (composed of weakly locked or poorly cemented sands, soft sandstones, clay, shale or soft limestones such as Chalk) (Jones and Lee 1994; Lee and Clark 2002). The hard cliffs in England and Wales are more resilient to erosion, so there are less defences and thus fewer set-backs have developed compared to the more heavily defended soft rock cliffs. In low-lying areas, the softer rock regions still dominate, but there is a greater occurance of set-backs or set-forwards in hard rock areas compared with cliffs, due to the prevalance of harbour arms and jetties. Thus, for low-lying coasts, the relationship of set-back and set-forward sites in relation to bed geology is less strong compared with cliffed coasts. Hence for low-lying coasts other factors such as coastal geomorphology and socio-economic factors are more important than bed geology in determining set-back and set-forward location.

Figure 7 illustrates the eroding coasts of England and Wales (Jones and Lee 1994). 82 out of 95 (86\%) cliffed set-backs or set-forwards, and 51 out of $95(54 \%)$ low-lying setbacks or set-forwards are located in areas defined as eroding. The remaining sites are on stable or accreting coasts. Erosion may occur on these coasts, but is too localised and too small to resolve on a national-scale map. Along stable or accreting coasts, set-backs or setforwards often occur near rivers, harbour mouths or flood defences. Some of these occur naturally, but may be enhanced by coastal structures. For instance, sediment accumulation 
results in a set-forward, developing where jetties or breakwaters have been constructed to improve navigation, such as Black Buoy Sands, The Wash, Lincolnshire.

Case studies and long terms implications of set-backs.

Examples of known prominent set-backs, with a cross-shore depth of tens to hundreds of metres, include Bridlington in East Riding of Yorkshire, Lyme Regis in Dorset, and Bartonon-Sea in Hampshire. These sites have either had littoral drift barriers for hundreds of years and/or more rapid retreat in recent decades. Bridlington has been defended for at least 800 years (East Riding of Yorkshire Council 2004) to create a harbour and has a 700m deep setback down-drift. Lyme Regis has been artificially controlled by defences since The Cobb was constructed in the $13^{\text {th }}$ century and has undergone substantial modification resulting in multiple set-backs down-drift (Figure 8). At Barton-on-Sea the defences were constructed from 1964 and since then have created an approximate 60m set-back down drift (Figure 2). Thus the size of an active set-back depends upon the period since defence construction, and the rate of erosion. Sites with a long history of (often multiple) set-backs such as Bridlington illustrate historic settlement patterns, whereas others have been partly due to a growing population base and tourist industry with the construction of promenades from the mid $19^{\text {th }}$ century, as for instance, Blackpool, Lancashire. Set-backs have sometimes developed where coastal defences terminate at a local authority boundary (or for early defences, the parish boundary), for example, at Highcliffe / Naish Farm on the Hampshire / Dorset boundary and the boundary of Blackpool / St Annes in Lancashire.

Figures 5 and 6 show the localities of set-backs and set-forwards, not the actual number. To determine the number of these, a more detailed study is required of each locality. 
Multiple set-backs may occur at sites where defences have been progressively extended. The earlier set-backs are inactive, or 'fossilised', while those at the defence extremities are active; the former representing coastal engineering works of previous decades or centuries ago. Hornsea, located on the Holderness coast of East Yorkshire has multiple set-backs caused by multiple defence extensions (Figure 9). Sediment has been retained up-drift after each extension, causing starvation down-drift, further exacerbating the down-drift erosion problem. The earliest substantial defences were constructed in 1906 (East Riding of Yorkshire Council 2004; Valentin 1954), resulting in set-back up and down-drift. Although the defences were extended on five occasions up and down-drift (East Riding of Yorkshire Council 2004), only three set-backs (two down-drift and one up-drift) can be seen from the planform shape. This is because insufficient time has passed in the periods between defence construction (years rather than several decades) to allow all the potential set-backs to develop. Hence, the $200 \mathrm{~m}$ cross-shore set-back down-drift active today is dominantly a product of all disturbances due to defence construction. Extensive retreat adjacent to defences can lead to headland formation, where stable bays can evolve between headlands (Silvester 1960). Other localities with multiple fossilised and active set-backs include Cromer, Norfolk and Lyme Regis, Dorset which are ideal sites to study the influence of defences on the adjacent coast, the growth of down-drift set-backs, and headland formation.

The study of set-backs reveals much about co-evolution of the physical coast and society, recording the coastal engineers' challenge to overcome erosion and outflanking. It also raises the question of how we will manage the coast in the future. As the hard engineered approach to coastal management shifts to softer techniques, Shoreline Management Plans will propose managed realignment and defence abandonment in many locations (Department for Environment, Food and Rural Affairs 2009) ('Type 4' of the set- 
backs and set-forwards identified in the 'Introduction'). Subsequently, set-backs, particularly on the softer rock coasts of Southern and Eastern regions of England may become more common in the medium-term (i.e. decades). Furthermore, as the Southern and Eastern regions of the country are also sinking due to isostatic adjustment, they have, and will continue to experience a greater need for protection. This has led, and could potentially lead to a large number of set-backs or set-forwards. However, in the long-term (over a century), the number of set-backs will probably reduce as selective defences remain, leaving only large (and still evolving) set-backs. As coastlines continue to become set back adjacent to defences, the protected shoreline stands increasingly seaward, becoming more exposed to wave attack owing to wave refraction and diffraction. For example, at Hornsea, Holderness (Figure 9) over many decades the defences have formed an artificial headland or promontory. Sediment has accumulated up-drift (reducing retreat), reinforcing a deficit down-drift (resulting in increased retreat). This has led to extensive loss of land and infrastructure, as well as the progressive outflanking of defences, making them ineffective at the extremities. Hence it is important to monitor coastal change, especially down-drift retreat rates and to anticipate land and infrastructure loss. Where defences become headlands (such as areas where land values and population levels are high), they must be progressively upgraded to cope with the increased wave loadings due to increased refraction as the headland grows. Bays will form between adjacent headlands and experience lower levels of retreat than other more exposed parts of the coast (Silvester 1960).

This paper has identified broad-scale principles and controls concerning the distribution of set-backs. However, it does not and cannot explain why and how individual set-backs develop on a small scale, and how they interrupt the littoral drift system. This requires detailed study of cases which can be selected from the dataset (see Appendix). The 
ideal study sites are not necessarily where there are a high density of set-backs, but where enough time has passed to create a sizeable set-back and where sufficient and appropriate data are available.

\section{Conclusions}

This study provides a national picture of the causes and location of set-backs and setforwards in England and Wales, including a list of sites which can be considered in future studies. Five major conclusions are apparent:

- Coastal defences hold shoreline position and alter the sediment budget resulting in retreat (due to sediment starvation) or advance (due to sediment accretion) of the adjacent coast.

- Set-backs (retreat) and set-forwards (accretion) have been mapped in England and Wales by analysing mean high and low water and the cliff base and cliff top. 190 localities have been found to be set-back or set-forward, with equal numbers of sites on cliffed and low-lying coasts.

- Defences are constructed when soft eroding material requires protection, or where low-lying land is vulnerable to flooding. It follows that nationally, these factors control the location of set-backs or set-forwards. These conditions are most common on the South East and Eastern coasts of England, where half of all localities are situated.

- Some sites have multiple set-backs. The set-back sites at the extremity of the defence are actively eroding, whilst other set-backs are inactive where the protection has been extended. With defence abandonment, set-backs are likely to become more common in the short-term. However over the longer term as fewer defences remain, there is 
likely to be a smaller number of set-backs, but these will tend to be larger in magnitude and potentially create significant artificial headlands. Where artificial headlands evolve, set-backs may form a stable shoreline between headlands.

- With continued evolution of the coast, the hazards to housing and infrastructure resulting from set-backs (which are potential 'hotspots' of erosion) will remain an important feature to monitor, analyse and manage in the coming decades.

\section{Acknowledgements}

SB is grateful for the receipt of an EPSRC funded studentship during the course of this research. Thanks are given to the anonymous reviewers whose comments helped improve this paper. Map outlines (Figures 5, 6, 7, and 9) (C) Crown Copyright and Landmark Information Group Limited (2011). An Ordnance Survey/EDINA supplied service. All rights reserved. http://edina.ac.uk/digimap

\section{References}

Anderson GL, Hardaway CS, Gunn JR (1983) Beach response to spurs and groins. Proc Coast Structures '83. Arlington, Virginia 727-739

Bird ECF (1985) Coastline changes : a global view. John Wiley and Sons, Chichester

Bishop CH (1973) Folkestone: The story of a town. Headley Brothers Limited, London and Ashford 
Brampton A (2002) ICE design and practice guides: Coastal defence. Thomas Telford, London

Brown S (2008) Soft cliff retreat adjacent to coastal defences, with particular reference to Holderness and Christchurch Bay, UK. PhD dissertation, University of Southampton, Southampton, UK

Brown S, Barton ME, Nicholls RJ (submitted) The effect of coastal defences on cliff top retreat along the Holderness coastline. Submitted to Proc Yorks Geol Soc

Bruun P (1995) The development of downdrift erosion. J Coast Res 11:1242-57

Bruun P (2001) The development of downdrift erosion: an update of paper in JCR, Vol 11, (4). J Coast Res 17:82-89

Coastal Concern Action Group (2008) Timeline. http://www.happisburgh.org.uk/campaign/timeline Accessed March 2011

Crowell M, Leatherman SP, Buckley MK (1991) Historical shoreline change: Error analysis and mapping accuracy. J Coast Res 7:839-52

Dean RG (1996) Interaction of littoral barriers and adjacent beaches: Effects on profile shape and shoreline change. J Coast Res SI 23:103-12 
Department for Environment, Food and Rural Affairs (2009) Shoreline Management Plans. http://www.defra.gov.uk/environment/flooding/policy/guidance/smp.htm Accessed March 2011

East Riding of Yorkshire Council (2004) Coastal information pack. East Riding of Yorkshire's coastline. Flamborough Head to Spurn Point. http://www.eastriding.gov.uk/az/az_details_new?az_selected=967 Accessed March 2011

Eurosion (2004) Living with coastal erosion in Europe: sediment and space for sustainability. Part IV - A guide to coastal erosion management practices in Europe: Lessons learned. http://www.eurosion.org/reports-online/part4.pdf Accessed March 2011

Evans E, Ashley R, Hall J, Penning-Roswell E, Sayers P, Thorne P, Watkinson, A (2004) Foresight, Future flooding scientific summary: Volume II - Managing future risks. Office of Science and Technology, London

Galgano FA (1998) Geomorphic analysis of modes of shoreline behavior and the influence of tidal inlets on coastal configuration. University of Maryland, Maryland

Google (2011) Google Earth. http://earth.google.com. Accessed March 2011

Halcrow (2002) Futurecoast (3 CD set comprising reports and interactive map browser with oblique aerial photography of the shoreline of England and Wales). Obtained from the Department for Environment, Food and Rural Affairs (DEFRA), for information see 
http://www.halcrow.com/Our-projects/Project-details/Futurecoast-England/ Accessed March 2011

Hewitt W (1844) An essay on the encroachments of the German Ocean along the Norfolk Coast, with a design to arrest its further depredations. Matchett, Stevenson and Matchett, Norwich

Hutchinson JN, Bromhead EN, Lupini JF (1980) Additional observations on the Folkestone Warren landslides. Q J Eng Geol, London 13:1-31

Jones DKC, Lee EM (1994) Landsliding in Great Britain. HMSO, London

Kana TW, White TE, McKee PA (2004) Management and engineering guidelines for groin rehabilitation. J Coast Res SI 33:57-82

Komar PD (1976) Beach processes and sedimentation. Prentice-Hall Inc., New Jersey

Leafe R, Pethick J, Townend I (1998) Realizing the benefits of shoreline management. Geog J $164: 282-290$

LeBlond PH (1972) Formation of spiral beaches. Proceedings of the thirteenth coastal engineering conference. Vancouver, Canada, pp1331-1346

Lee EM, Clark AR (2002) Investigation and management of soft rock cliffs. Thomas Telford, London 
Nicholls RJ, Dredge A, Wilson T (2000) Shoreline change and fine-grained sediment input: Isle of Sheppey Coast, Thames Estuary, UK. In: Pye K, Allen JRL (eds) Coastal and Estuarine Environments: Sedimentology, geomorphology and geoarchaeology. Geological Society, London, pp 305-315.

Silvester R (1960) Stabilization of sedimentary coastlines. Nature 4749:467-69

Steers JA (1951) Notes on erosion along the coast of Suffolk. Geol Mag 88: 435-439.

Terpstra PD, Chrzastowski MJ (1992) Geometric trends in the evolution of a small log-spiral embayment on the Illinois shore of Lake Michigan. J Coast Res 8:603-17

Valentin H (1954) Land loss at Holderness. Reprinted in 1971 in: Steers JA (ed) Applied coastal geomorphology. Macmillan, London, pp 116-137

West Dorset District Council (2002) West Bay coastal defence and harbour improvements scheme. Information leaflet. http://www.dorsetforyou.com/media.jsp?mediaid=348\&filetype=Document Accessed March 2011 
i) Before defence construction

Unprotected eroding coast

Beach

Longshore drift

ii) Defence construction

Coast protected by defences

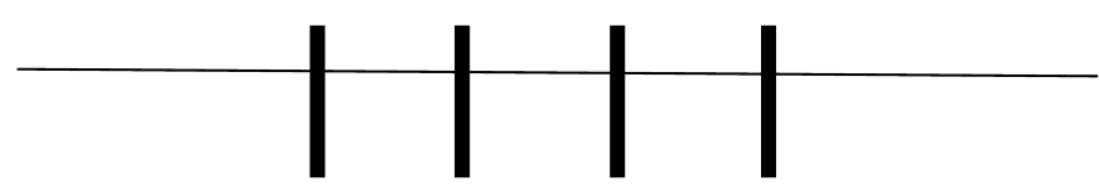

iii) After defence construction

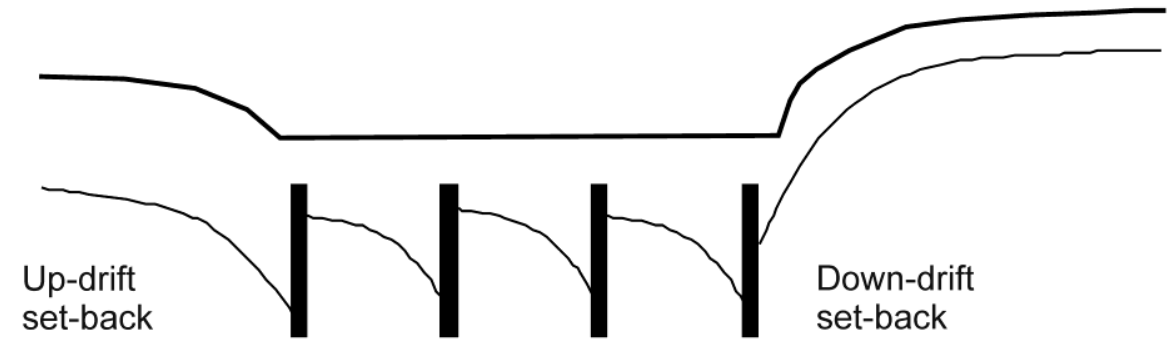

Figure 1a 


\section{i) Before defence construction}

Unprotected eroding coast: back of beach or cliff base

High tide mark

Longshore drift

ii) Defence construction

Unprotected eroding coast: back of beach or cliff base

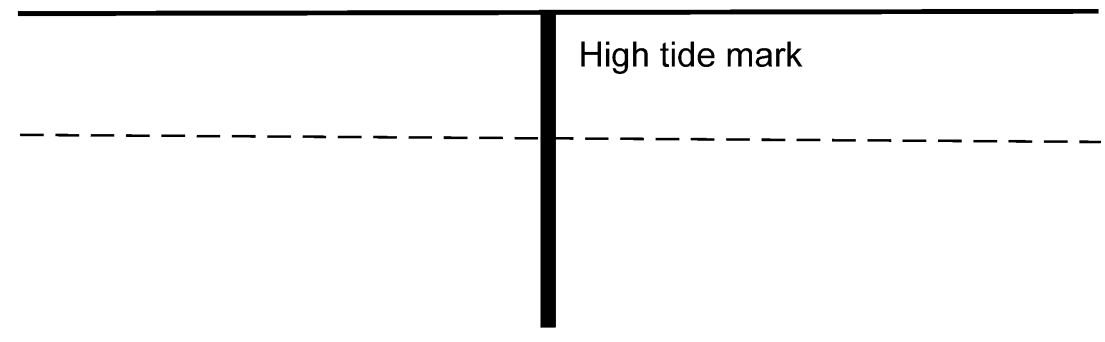

iii) After defence construction

Unprotected eroding coast: back of beach or cliff base

High tide mark
Up-drift
set-forward

Figure 1b 


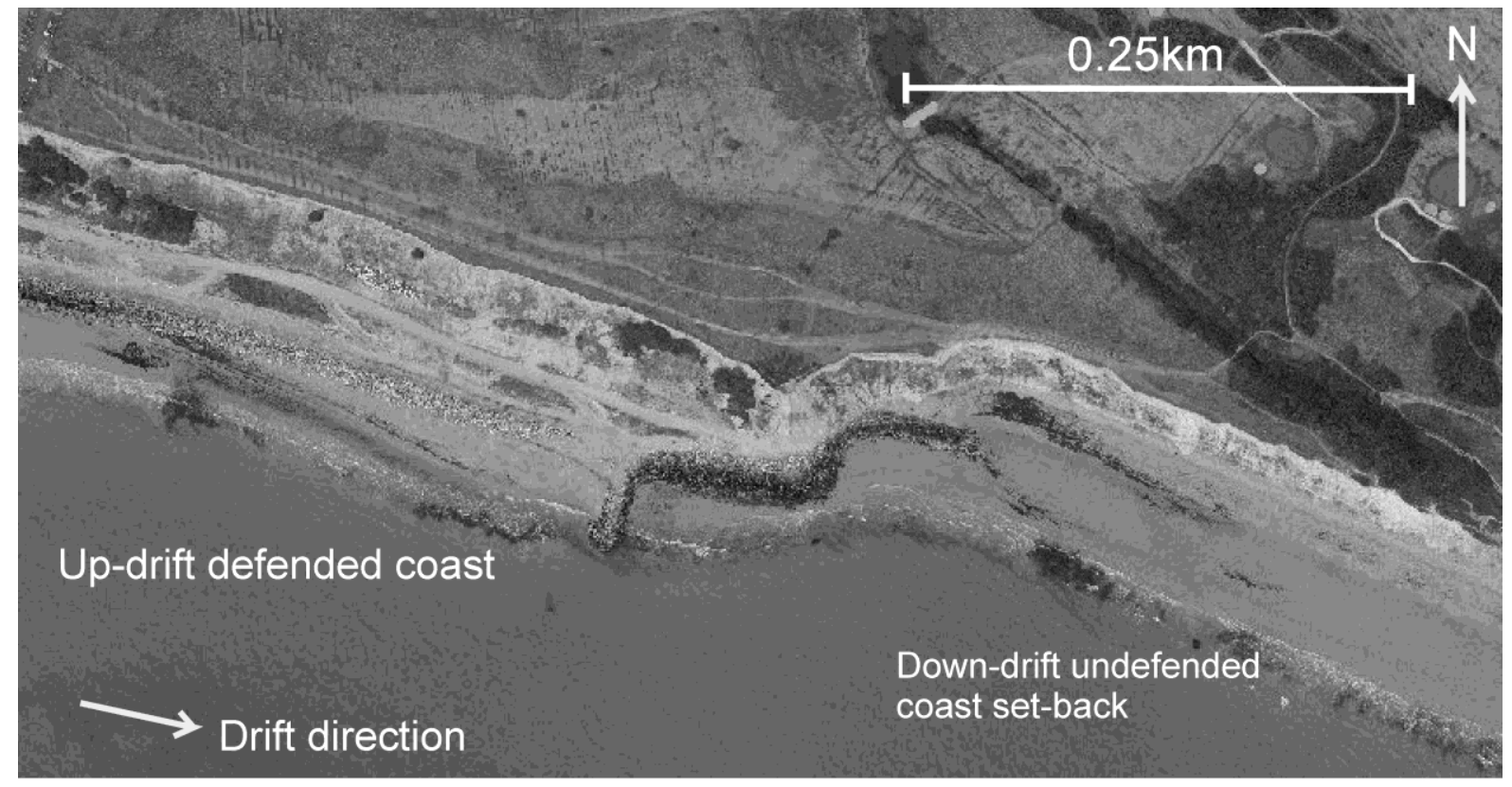

\section{Figure 2}

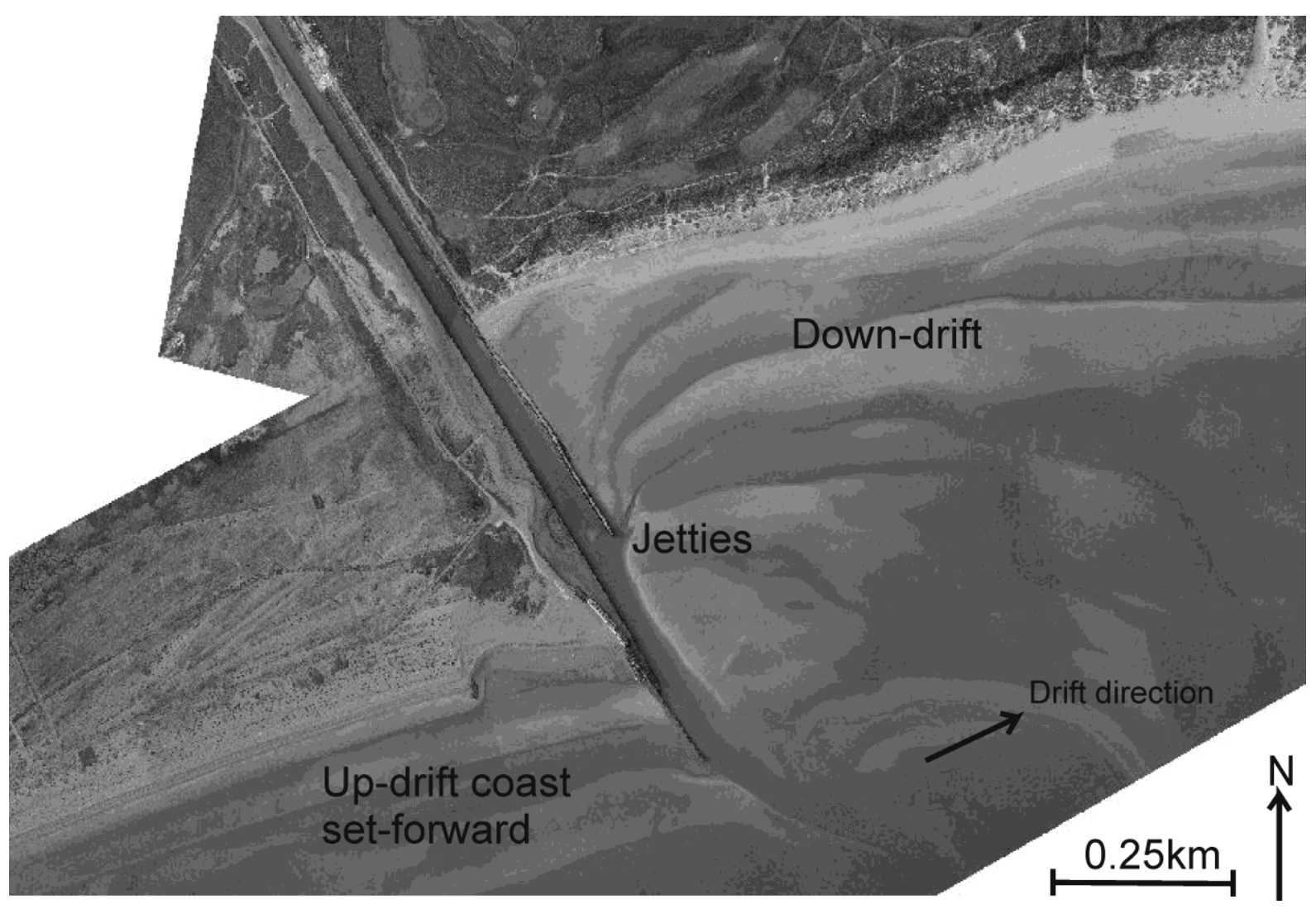

Figure 3 


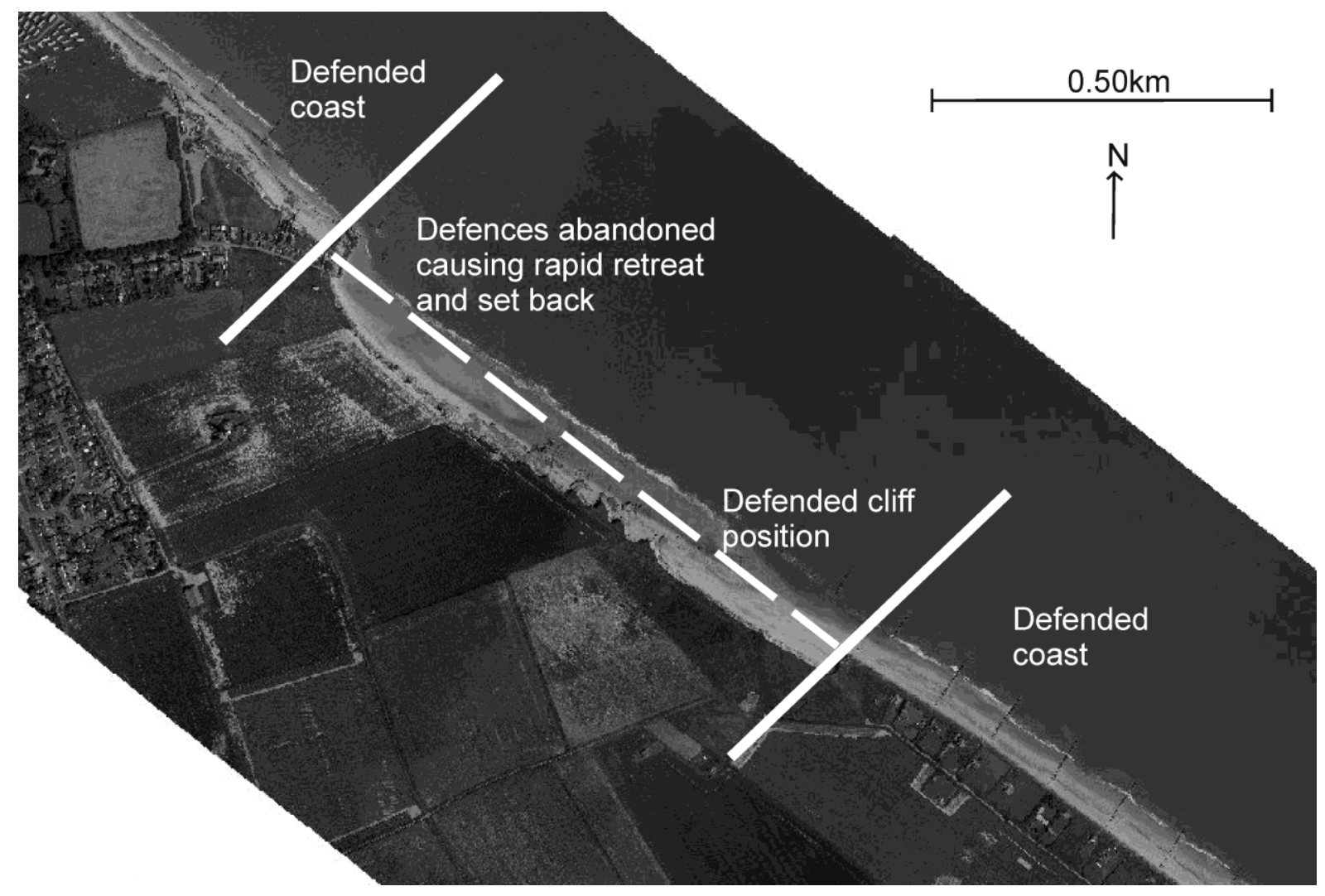

Figure 4 


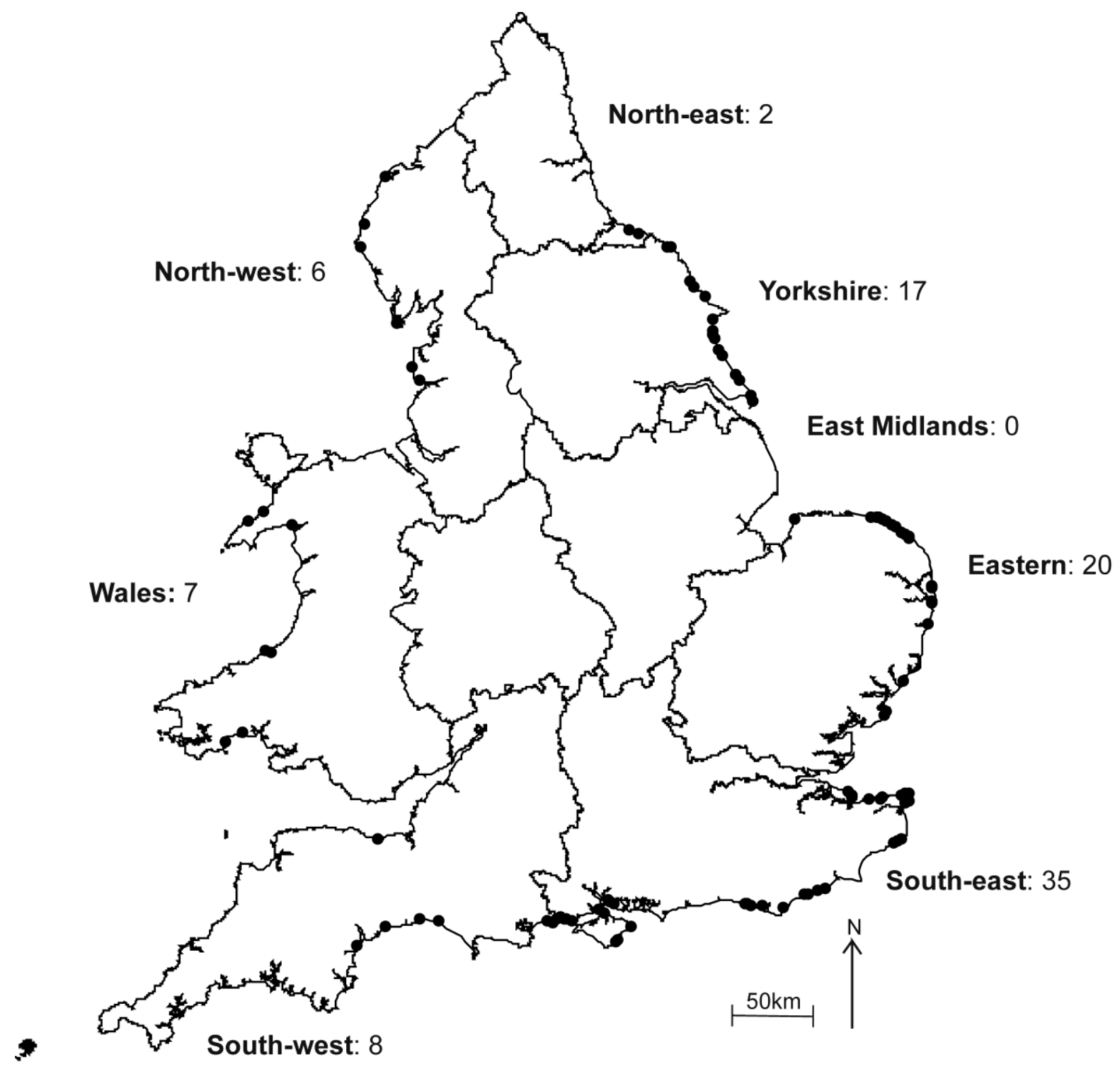

Figure 5 


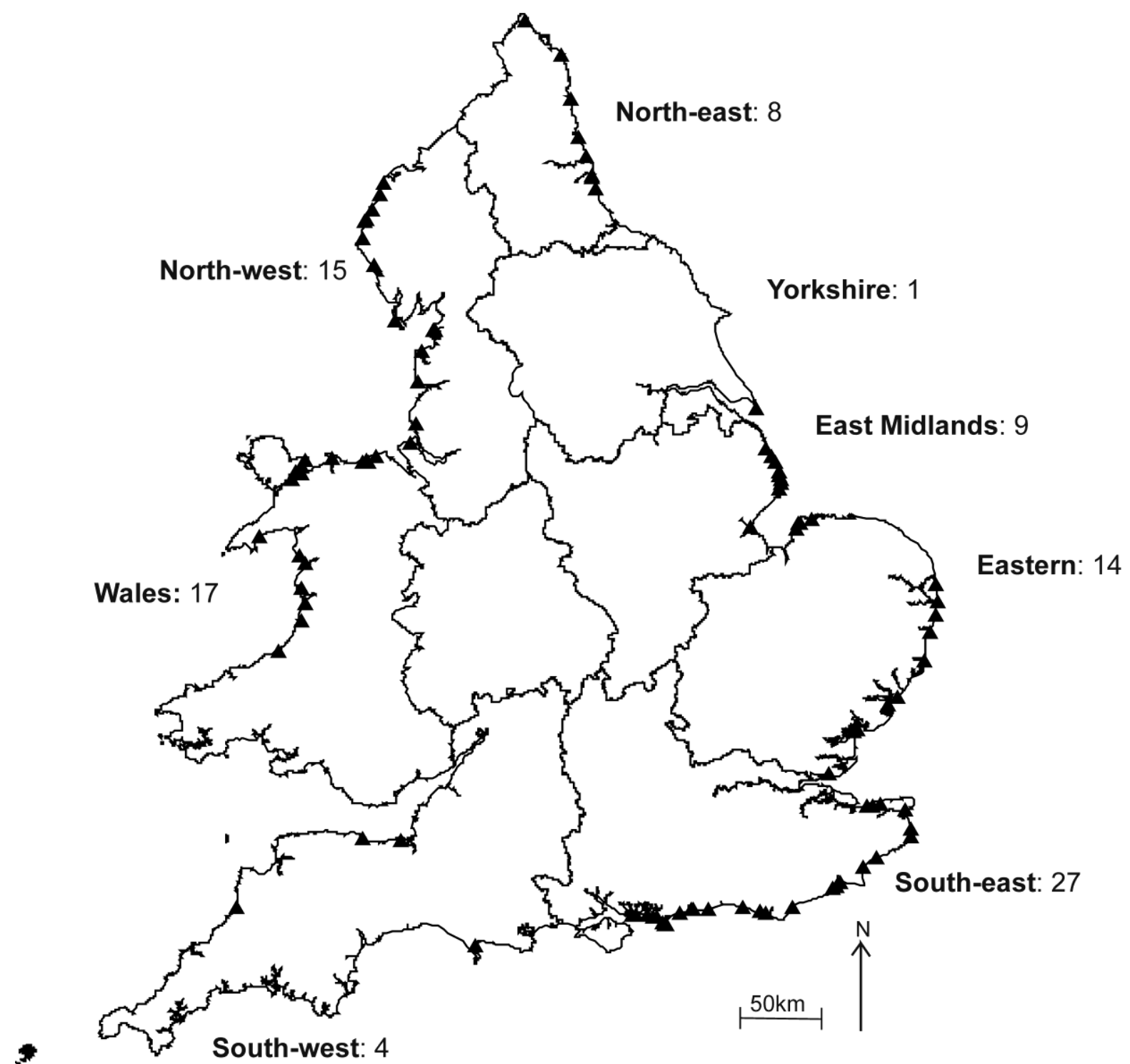

Figure 6 


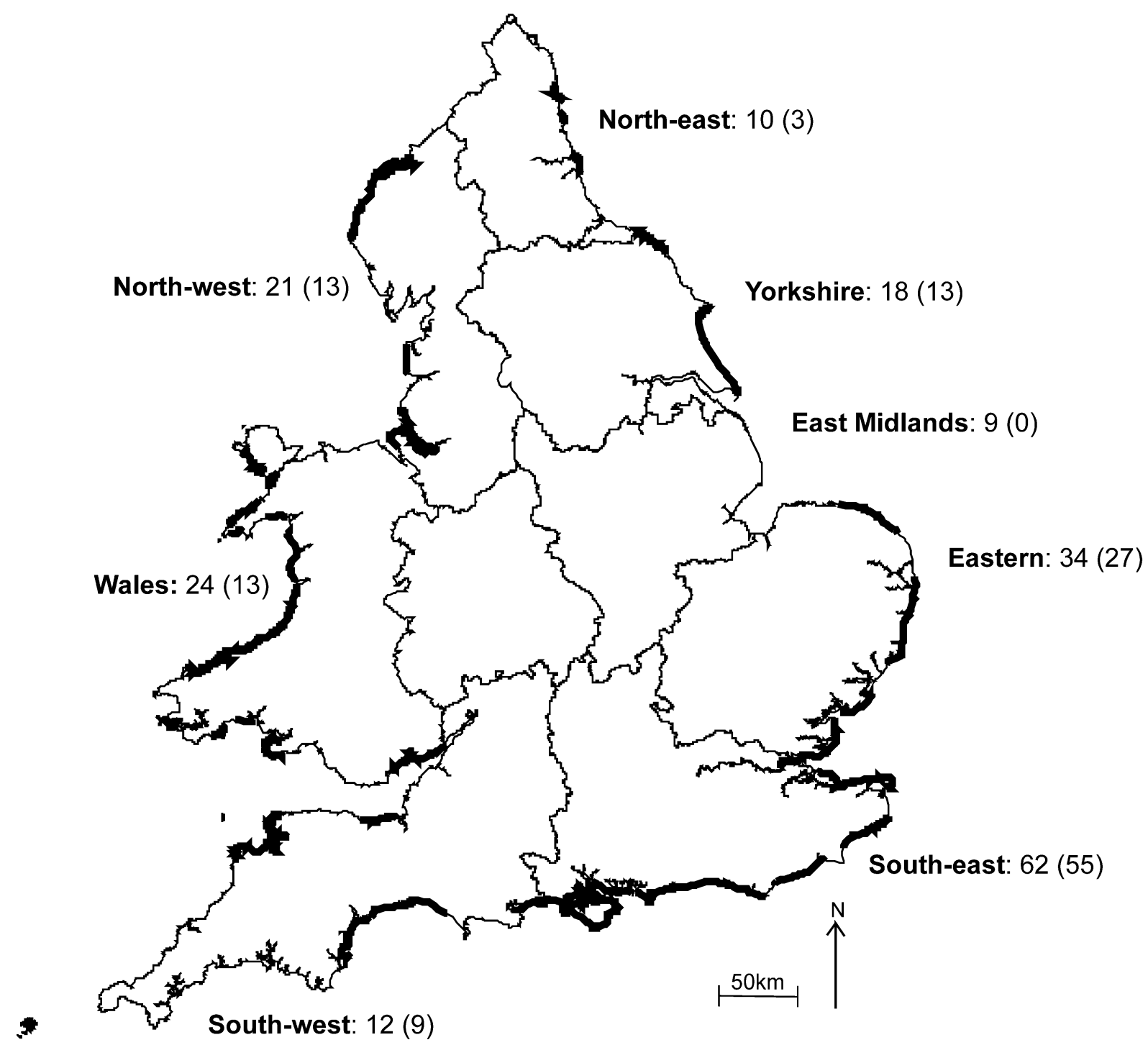

Figure 7 


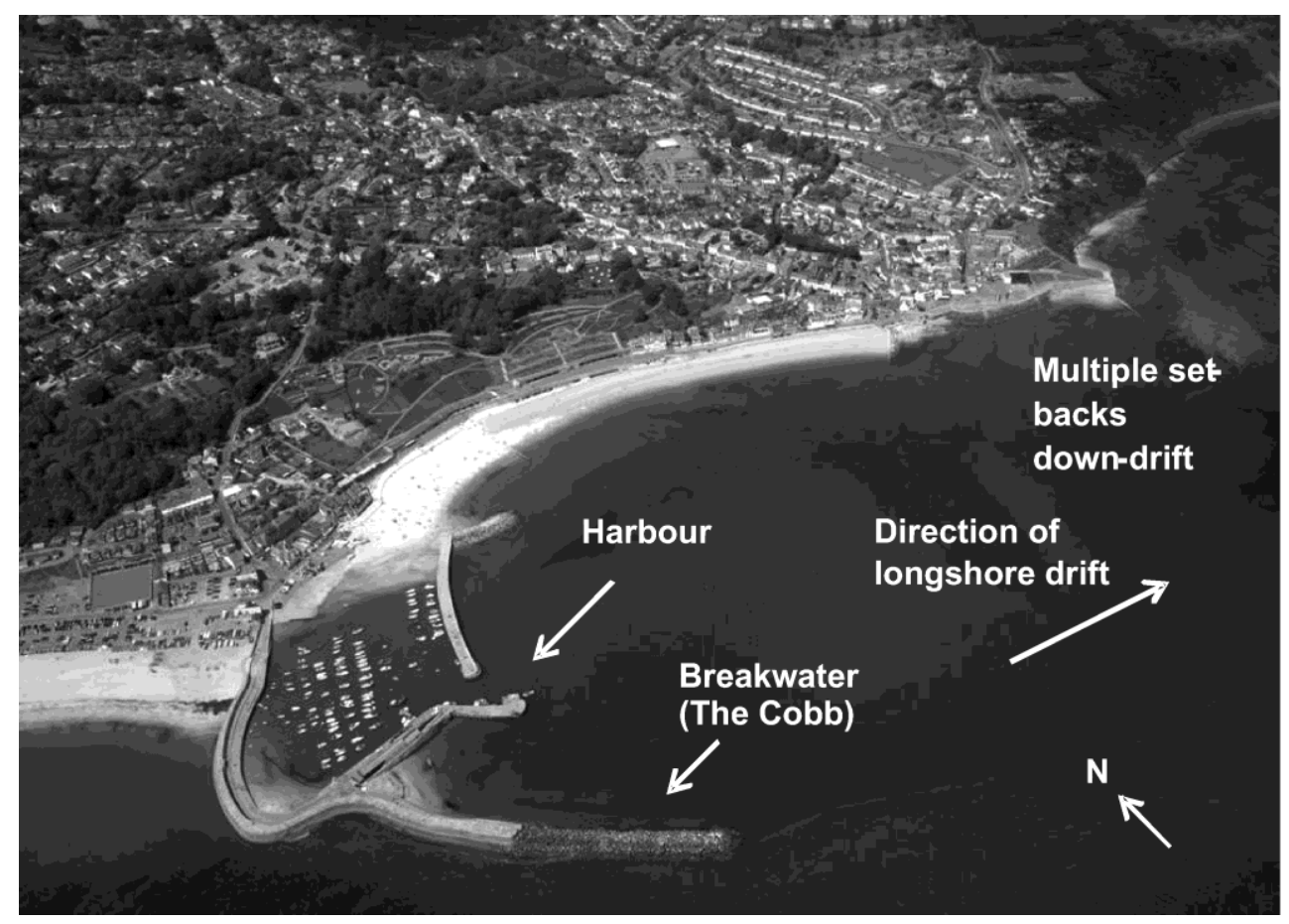

\section{Figure 8}

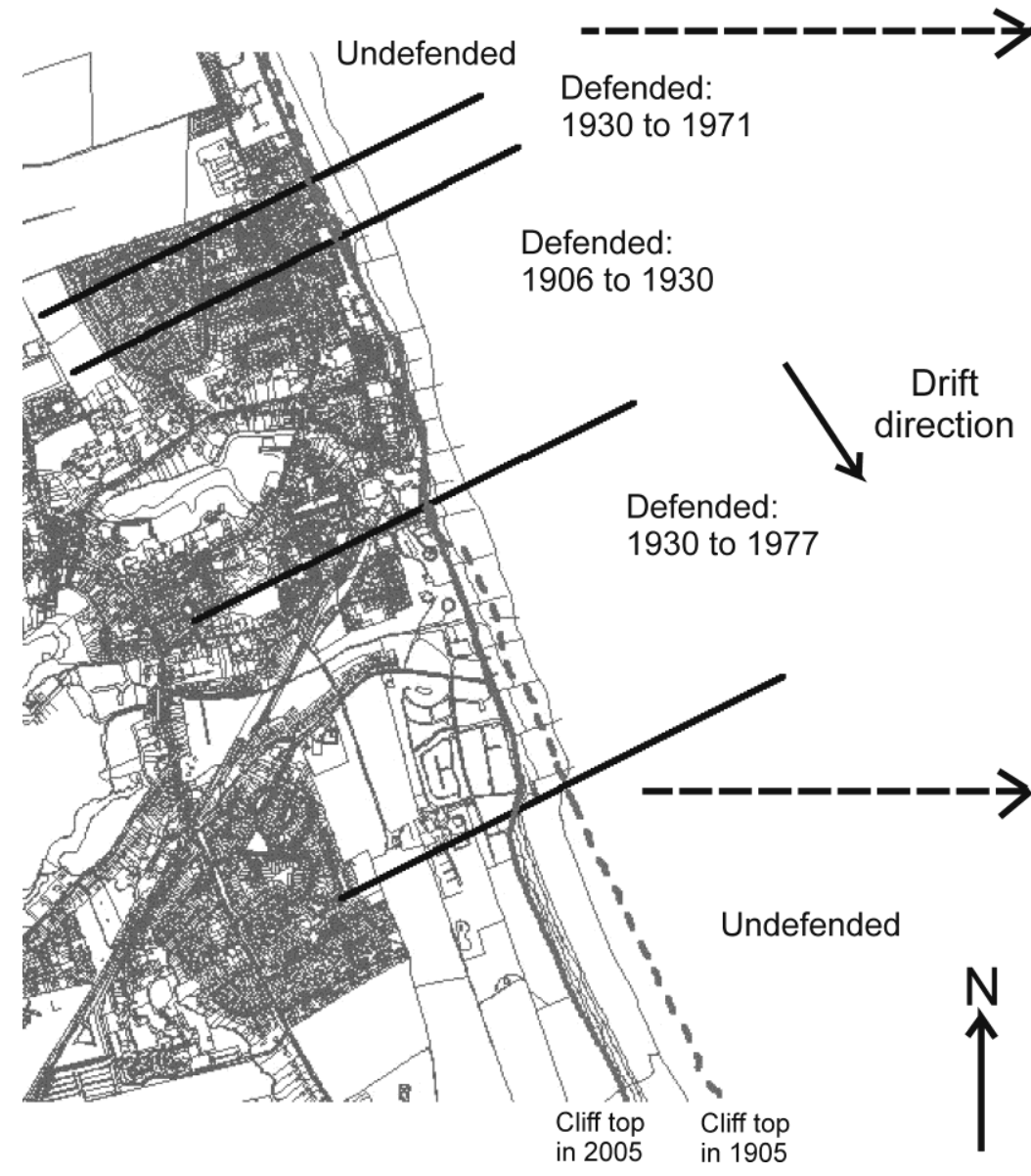

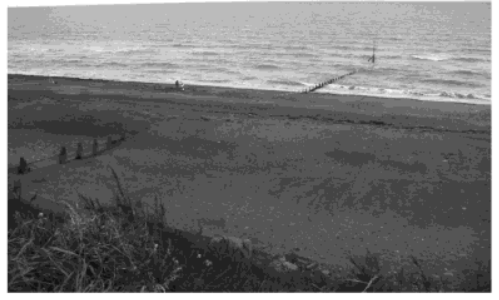

Up-drift defences

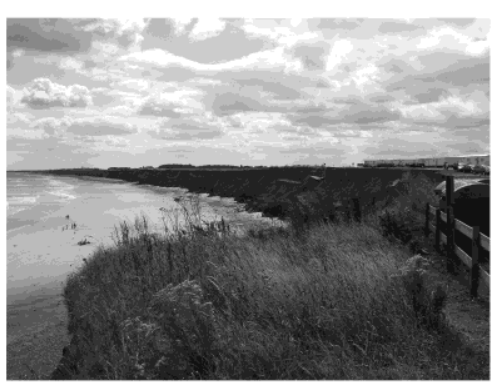

Down-drift of defences

$1 \mathrm{~km}$

\section{Figure 9}




\section{Figure captions}

Fig. 1a Formation of set-back adjacent to defences on a cliffed coast: i) 'Straight' coastline before defence construction; ii) Defence construction; iii) Coastline after defence construction where the down-drift coast is set back further than the up-drift coast. The latter would continue to retreat but at a slower rate than the down-drift coast because of the protection afforded by the greater width of beach

Fig. 1b Formation of a set-forward adjacent to defences on beaches: i) 'Straight' coastline before defence construction; ii) Defence construction; iii) Coastline after defence construction where sediment accumulates up-drift causing the coast to be set-forward (here, the back of the beach has not retreated)

Fig. 2 Set-back in a cliffed setting down-drift of the Barton-on-Sea defences, Hampshire. 2005 aerial photograph courtesy of the Channel Coastal Observatory, Southampton http://www.channelcoast.org

Fig. 3 Set-forward in a low-lying setting at Rye, East Sussex. 2005 aerial photograph courtesy of the Channel Coastal Observatory, Southampton http://www.channelcoast.org

Fig. 4 Defence abandonment and removal causing set-back of the undefended coast adjacent to the remaining defences at Happisburgh, Norfolk. 2005 aerial photograph courtesy of North Norfolk District Council 
Fig. 5 Set-backs and set-forwards located in a cliffed setting in England and Wales (circle symbol). Map outline (C Crown Copyright and Landmark Information Group Limited (2011). An Ordnance Survey/EDINA supplied service

Fig. 6 Set-backs and set-forwards located in a low-lying setting in England and Wales (triangle symbol). Map outline (C Crown Copyright and Landmark Information Group Limited (2011). An Ordnance Survey/EDINA supplied service

Fig. 7 The eroding coastline of England and Wales as defined by Jones and Lee (1994) (bold lines). Note comparison with the total number of set-backs and set-forwards in Figures 5 and 6, with the number situated on eroding coastlines in brackets. Map outline (C) Crown Copyright and Landmark Information Group Limited (2011). An Ordnance Survey/EDINA supplied service

Fig. 8 Progressive multiple set-backs down-drift of Lyme Regis, Dorset. 2007 aerial photograph. Photograph courtesy of West Dorset District Council

Fig. 9 Multiple set-backs (two down-drift, one up-drift) and headland formation at Hornsea, Holderness, Yorkshire. Map (C) Crown Copyright and Landmark Information Group Limited (2011). An Ordnance Survey/EDINA supplied service. All rights reserved. http://edina.ac.uk/digimap 


\section{Tables}

Table 1 The number of sites with set-backs and set-forwards in England and Wales (as shown in Figures 5 and 6) according to region, topography and whether the coast is eroding (as defined by Jones and Lee 1994 and shown in Figure 7). Note that whilst most of these sites have a set-back down-drift of defence works, some also have a set-forward on the updrift side

\begin{tabular}{|c|c|c|c|c|c|c|c|}
\hline \multirow[b]{2}{*}{ Region } & \multicolumn{2}{|c|}{ Cliffs } & \multirow[b]{2}{*}{ Total } & \multicolumn{2}{|c|}{ Low-lying } & \multirow[b]{2}{*}{ Total } & \multirow{2}{*}{$\begin{array}{l}\text { Grand } \\
\text { Total }\end{array}$} \\
\hline & Eroding & $\begin{array}{l}\text { Stable or } \\
\text { accreting }\end{array}$ & & Eroding & $\begin{array}{l}\text { Stable or } \\
\text { accreting }\end{array}$ & & \\
\hline North East & 0 & 2 & 2 & 3 & 5 & 8 & 10 \\
\hline Yorkshire & 13 & 4 & 17 & 0 & 1 & 1 & 18 \\
\hline East Midlands & 0 & 0 & 0 & 0 & 9 & 9 & 9 \\
\hline Eastern & 18 & 2 & 20 & 9 & 5 & 14 & 34 \\
\hline South East & 33 & 2 & 35 & 22 & 5 & 27 & 62 \\
\hline South West & 8 & 0 & 8 & 1 & 3 & 4 & 12 \\
\hline Wales & 7 & 0 & 7 & 6 & 11 & 17 & 24 \\
\hline North West & 3 & 3 & 6 & 10 & 5 & 15 & 21 \\
\hline Total & 82 & 13 & 95 & 51 & 44 & 95 & 190 \\
\hline
\end{tabular}




\section{Appendix}

Table A1 Set-back and set-forward sites plotted for cliffed coasts in Figure 5 and

discussed throughout the text. No distinction is made between sites which are set-back or set-forward as this requires detailed case studies (see 'Introduction')

\begin{tabular}{|c|c|c|}
\hline Region & Cliffs & Grid reference \\
\hline North East & $\begin{array}{l}\text { Marske-by-the-Sea } \\
\text { Brotton }\end{array}$ & $\begin{array}{l}464427521692 \\
470802520023 \\
\end{array}$ \\
\hline TOTAL: & 2 & \\
\hline Yorkshire & $\begin{array}{l}\text { North of Whitby } \\
\text { Whitby } \\
\text { Robin Hood's Bay } \\
\text { Scarborough } \\
\text { South of Scarborough } \\
\text { Filey } \\
\text { Bridlington } \\
\text { Barmston Caravan Park } \\
\text { Barmston Main Drain } \\
\text { Ulrome } \\
\text { Skipsea } \\
\text { Hornsea } \\
\text { Mappleton } \\
\text { Tunstall } \\
\text { Withernsea } \\
\text { Easington } \\
\text { Kilnsea }\end{array}$ & $\begin{array}{l}488808511356 \\
490821510931 \\
496957504221 \\
503185489475 \\
504537486919 \\
511558480821 \\
517133466219 \\
516763458808 \\
517188458731 \\
517072456989 \\
517769454589 \\
520206447792 \\
522528443843 \\
531266431642 \\
533915427983 \\
540357418613 \\
541441415594 \\
\end{array}$ \\
\hline TOTAL: & $\begin{array}{r}17 \\
\end{array}$ & \\
\hline Eastern & $\begin{array}{l}\text { Hunstanton } \\
\text { Sheringham } \\
\text { West Runton } \\
\text { East Runton } \\
\text { Cromer } \\
\text { Overstrand } \\
\text { Trimingham } \\
\text { Mundesley } \\
\text { Bacton } \\
\text { Ostend } \\
\text { Happisburgh } \\
\text { Whimpwell Green } \\
\text { Hopton-on-Sea } \\
\text { South of Hopton-on-Sea } \\
\text { North of Pakefield } \\
\text { South of Pakefield } \\
\text { Southwold } \\
\text { Bawdsey } \\
\text { Walton-on-the-Naze } \\
\text { Frinton-on-Sea }\end{array}$ & $\begin{array}{l}568020341573 \\
615008343029 \\
618221343107 \\
620195342681 \\
622904341946 \\
624235341021 \\
628338338699 \\
630816336647 \\
634532333473 \\
636699331848 \\
638402330802 \\
638751330183 \\
652942299930 \\
653445298846 \\
653532290718 \\
653106289557 \\
650572275975 \\
635115240559 \\
624631222112 \\
623199219132 \\
\end{array}$ \\
\hline TOTAL: & 20 & \\
\hline
\end{tabular}




\begin{tabular}{|c|c|c|}
\hline South East & $\begin{array}{l}\text { Warden Point, Sheppey } \\
\text { Leysdown-on-Sea, Sheppey } \\
\text { South of Leydown-on-Sea, Sheppey } \\
\text { Swalecliffe } \\
\text { East of Herne Bay } \\
\text { Hillborough } \\
\text { West of Maragate } \\
\text { East of Margate } \\
\text { Long Nose Spit } \\
\text { North of Ramsgate } \\
\text { South of Ramsgate } \\
\text { East of Dover } \\
\text { West of Dover } \\
\text { Far west of Dover } \\
\text { Fairlight } \\
\text { Hastings } \\
\text { East Bexhill } \\
\text { West Bexhill } \\
\text { Eastbourne } \\
\text { Seaford } \\
\text { East of Peacehaven } \\
\text { West of Peacehaven } \\
\text { Rottingdean } \\
\text { Hill Head } \\
\text { Stubbington } \\
\text { Titchfield } \\
\text { Lepe } \\
\text { Gurnard } \\
\text { Bembridge } \\
\text { East Ventnor } \\
\text { West Ventnor } \\
\text { Milford-on-Sea } \\
\text { Becton } \\
\text { Barton-on-Sea } \\
\text { Highcliffe / Naish Farm }\end{array}$ & $\begin{array}{l}600844172108 \\
603249170059 \\
603831169095 \\
613776167088 \\
620976167978 \\
622574168437 \\
633993170179 \\
636703170915 \\
638948170876 \\
638579166080 \\
636256164803 \\
634482143072 \\
631308141678 \\
629567140014 \\
586796112329 \\
582453110252 \\
576083108609 \\
573954107913 \\
561170099809 \\
547689100552 \\
540257101597 \\
538709101946 \\
536773102720 \\
454869102618 \\
452788103916 \\
451162104419 \\
445371099049 \\
448710095873 \\
465312087968 \\
458047079229 \\
456112078106 \\
428715092136 \\
425463093065 \\
424341093142 \\
422018093800 \\
\end{array}$ \\
\hline TOTAL: & 35 & \\
\hline South West & $\begin{array}{l}\text { Steamer Point } \\
\text { Hengistbury Head } \\
\text { Bournemouth } \\
\text { West Bay } \\
\text { Lyme Regis } \\
\text { Sidmouth } \\
\text { South of Dawlish } \\
\text { Watchet }\end{array}$ & $\begin{array}{l}419310093070 \\
417650090784 \\
413586091829 \\
346345091133 \\
333902092623 \\
312507087827 \\
295466075967 \\
308731142595 \\
\end{array}$ \\
\hline TOTAL: & 8 & \\
\hline Wales & $\begin{array}{l}\text { Pendine } \\
\text { Saundersfoot } \\
\text { New Quay } \\
\text { Cei Bach } \\
\text { Porthmadog } \\
\text { Carreg Ddu } \\
\text { Trefor }\end{array}$ & $\begin{array}{l}223677208725 \\
213506203640 \\
238241259542 \\
241808259126 \\
254523338211 \\
227591340350 \\
236812346428\end{array}$ \\
\hline TOTAL: & 7 & \\
\hline
\end{tabular}




\begin{tabular}{|l|l|l|}
\hline North West & Lytham St Anne's & 334064428247 \\
& Blackpool & 329414436324 \\
& Sheep Island / South End & 320137463800 \\
& St Bees & 297431511606 \\
& Harrington & 300035525463 \\
& Skinburness & 312601555616 \\
\hline TOTAL & \multicolumn{1}{|c|}{$\mathbf{6}$} & \\
\hline GRAND TOTAL: & $\mathbf{9 5}$ & \\
\hline
\end{tabular}

Table A2 Set-back and set-forward sites plotted for low-lying coasts in Figure 6 and discussed throughout the text. No distinction is made between sites which are set-back or set-forward as this requires detailed case studies (see 'Introduction')

\begin{tabular}{|c|c|c|}
\hline Region & Low-lying & Grid reference \\
\hline North East & $\begin{array}{l}\text { Berwick-upon-Tweed } \\
\text { North Sunderland Seahouses } \\
\text { Amble } \\
\text { Blyth } \\
\text { Tynemouth } \\
\text { Sunderland } \\
\text { Hendor, Sunderland } \\
\text { Seaham }\end{array}$ & $\begin{array}{l}398609653340 \\
421125631857 \\
426711604305 \\
431366580884 \\
436465568820 \\
439783557828 \\
440092555815 \\
442329548998\end{array}$ \\
\hline TOTAL: & 8 & \\
\hline Yorkshire & Spurn & 541712412884 \\
\hline TOTAL: & 1 & \\
\hline East Midlands & $\begin{array}{l}\text { Theddlethorpe St Helen } \\
\text { Trusthorpe, Mapplethorpe } \\
\text { South of Sandilands } \\
\text { Authorpe } \\
\text { Chapel St Leonards } \\
\text { North of Ingoldmells } \\
\text { South of Ingoldmells } \\
\text { Skegness } \\
\text { Black Buoy Sands }\end{array}$ & $\begin{array}{l}548002388556 \\
551369383678 \\
553227379305 \\
555509373857 \\
555702371922 \\
556734369409 \\
556928366932 \\
556378363393 \\
538404338797\end{array}$ \\
\hline TOTAL: & 9 & \\
\hline Eastern & $\begin{array}{l}\text { Heacham } \\
\text { East of Old Hunstanton } \\
\text { West of Old Hunstanton } \\
\text { Titchwell } \\
\text { Gorleston-on-Sea } \\
\text { Lowestoft } \\
\text { South of Kessingland / Benacre } \\
\text { Walberswick } \\
\text { Aldeburgh } \\
\text { Felixstowe } \\
\text { Harwich / Little Oakley } \\
\text { Mersea Flats }\end{array}$ & $\begin{array}{l}567130338051 \\
568272341920 \\
568737342307 \\
575879344390 \\
652748303453 \\
654112292615 \\
653613284661 \\
649140274427 \\
645953256205 \\
629096233367 \\
623251228606 \\
604504214195\end{array}$ \\
\hline
\end{tabular}




\begin{tabular}{|c|c|c|}
\hline & $\begin{array}{l}\text { West Mersea } \\
\text { Southend-on-Sea }\end{array}$ & $\begin{array}{l}601664212607 \\
587271185985 \\
\end{array}$ \\
\hline TOTAL: & 14 & \\
\hline South East & $\begin{array}{l}\text { Whitstable } \\
\text { East of Whitstable } \\
\text { West of Herne Bay } \\
\text { Ramsgate / Cliffs End } \\
\text { South of Deal } \\
\text { Kingsdown } \\
\text { Hythe } \\
\text { St Mary's Bay } \\
\text { Rye } \\
\text { Rye / Winchelsea } \\
\text { Winchelsea / Cliff End } \\
\text { Langney Point } \\
\text { Westdean } \\
\text { Newhaven } \\
\text { Brighton } \\
\text { Goring-by-Sea } \\
\text { Littlehampton } \\
\text { West of Littlehampton } \\
\text { Bognor } \\
\text { Church Norton / Pagham } \\
\text { East Selsey } \\
\text { West Selsey } \\
\text { East Wittering } \\
\text { West Wittering } \\
\text { South Hayling } \\
\text { Eastney } \\
\text { Southsea }\end{array}$ & $\begin{array}{l}610834166584 \\
613505166430 \\
618615167746 \\
634205164493 \\
637402151859 \\
637440147911 \\
615903134833 \\
608239127905 \\
594035119335 \\
591077116760 \\
588925114806 \\
564228103099 \\
547270099582 \\
544012100707 \\
533715104036 \\
512545102791 \\
501474101746 \\
502978101908 \\
494343099856 \\
483985094013 \\
486142092762 \\
485175093149 \\
480104097407 \\
477669098107 \\
474234098570 \\
466841099190 \\
464131098996\end{array}$ \\
\hline TOTAL: & 27 & \\
\hline South West & $\begin{array}{l}\text { Weymouth } \\
\text { Widemouth Bay / Bude } \\
\text { Minehead } \\
\text { Hinkley Point Power Station }\end{array}$ & $\begin{array}{l}368050079999 \\
218796102916 \\
297405145860 \\
321242145572 \\
\end{array}$ \\
\hline TOTAL: & 4 & \\
\hline Wales & $\begin{array}{l}\text { Aberaeron } \\
\text { Aberystwyth } \\
\text { Borth / Ynyslas } \\
\text { Tywyn } \\
\text { Barmouth } \\
\text { Tal-y-bont } \\
\text { Penthos } \\
\text { Penmon } \\
\text { Beamaris } \\
\text { Llandegfan } \\
\text { Vaynol Hall } \\
\text { Bangor } \\
\text { Llandudno } \\
\text { Towyn } \\
\text { West of Kinmel Bay } \\
\text { East of Kinmel Bay } \\
\text { Prestatyn }\end{array}$ & $\begin{array}{l}245640262145 \\
259183281372 \\
262084291532 \\
259428300934 \\
262006316943 \\
258846321034 \\
232967333765 \\
262288380948 \\
259876377288 \\
256589374184 \\
253528369409 \\
259648372210 \\
278354382069 \\
300791380009 \\
297764379897 \\
299777380671 \\
306086382993 \\
\end{array}$ \\
\hline
\end{tabular}




\begin{tabular}{|l|l|l|}
\hline TOTAL: & \multicolumn{1}{|c|}{$\mathbf{1 7}$} & \\
\hline North West & Wallasey & 327052391529 \\
& Hightown & 330729403899 \\
& Blackpool / St Annes & 332167429796 \\
& Fleetwood & 333878448191 \\
& Heysham Power Station & 342116461376 \\
& Heysham & 341910461611 \\
& Piel Island & 322517462199 \\
& Tummer Hill Scar & 318163467593 \\
& Seascale & 304540501415 \\
& Whitehaven & 297596518149 \\
& South of Workington & 298990528637 \\
& North of Workington & 299919530688 \\
& Maryport & 303511536480 \\
& Dubmill Point & 307924545654 \\
& Lees Scar Lighthouse & 310704552945 \\
\hline TOTAL & \multicolumn{2}{|c|}{$\mathbf{9 5}$} \\
\hline GRAND TOTAL: & \multicolumn{2}{|c|}{} \\
\hline
\end{tabular}

